Situs Jurnal : http://ejurnal.stiepancasetia.ac.id/index.php/jieb

Jilid 4 Nomor 2 Juli 2018

Hal 160 - 175

\title{
PENERAPAN PPH BADAN FINAL BERDASARKAN PERATURAN PEMERINTAH NO. 46 TAHUN 2013 PADA CV. YELLOW DUCK BANJARBARU
}

\section{Muhammad Zaini \& Yudi Rahman*}

Abstract: The purpose of this study is to analyze the implementation of the final corporate income tax based on Government Regulation no. 46 of 2013 on the CV. Yellow Duck Banjarbaru. This research uses descriptive data analysis method. Research conducted by the authors to give the conclusion, that: the implementation of Final Income Tax by Government Regulation No. 46 of 2013 on the CV. Yellow Duck Banjarbaru, concludes that: New tariff calculation based on PP. 46 of 2013 there is no need for fiscal correction, because the calculation is not from net income, but from gross income. So hopefully in the future, from the results of research provide input on the CV. Yellow Duck, to apply and make payments in the years to come. Implementation of the final corporate income tax based on Government Regulation no. 46 of 2013 on the CV. Yellow Duck Banjarbaru with annual gross turnover of less than Rp. 4.800.000.000, - that is Rp. 2.283.408.000, - in the period of 2016 with the rate of Corporate Tax 1\% then obtained the total value of corporate income amounting to Rp. 22.834.080, -. While the tax amnesty is the government policy given to taxpayers about forgiveness / forgiveness of taxes, and in exchange for the pardon the taxpayer is required to pay the ransom, obtained the value of corporate tax on the basis of tax amnesty rate of $0.5 \%$ with less gross revenue Rp. 4.800.000.000, - on the CV. Yellow Duck period 2016 is Rp. 11.417.040, - .

Keywords: PP 46 Year 2013, Corporate Income, CV. Yellow Duck

Abstrak: Tujuan penelitian ini untuk menganalisis penerapan $\mathrm{PPh}$ badan final berdasarkan Peraturan Pemerintah No. 46 Tahun 2013 pada CV. Yellow Duck Banjarbaru. Penelitian ini menggunakan analisis data metode deskriftif. Penelitian yang dilakukan oleh penulis memberikan kesimpulan, bahwa: penerapan PPh Badan Final berdasarkan Peraturan Pemerintah Nomor 46 Tahun 2013 pada CV. Yellow Duck Banjarbaru, memberikan kesimpulan bahwa: Perhitungan tarif baru berdasarkan PP No. 46 tahun 2013 tidak perlu dilakukan koreksi fiskal, karena perhitungannya bukan dari laba bersih, melainkan dari peredaran bruto. Sehingga diharapkan kedepannya, dari hasil penelitian memberikan masukan pada pihak CV. Yellow Duck, untuk diterapkan dan dilakukan pembayaran pada tahun-tahun kedepannya. Penerapan PPh badan final berdasarkan Peraturan Pemerintah No. 46 Tahun 2013 pada CV. Yellow Duck Banjarbaru dengan nilai peredaran bruto per tahun perusahaan kurang dari Rp. 4.800.000.000,- yaitu sebesar Rp. 2.283.408.000,- pada periode tahun 2016 dengan tarif PPh Badan 1\% maka diperoleh nilai total PPh Badan sebesar Rp. 22.834.080,-. Sementara dengan adanya tax amnesty yaitu kebijakan pemerintah yang diberikan kepada pembayar pajak tentang forgiveness/ pengampunan pajak, dan sebagai ganti atas pengampunan tersebut pembayar pajak diharuskan untuk membayar uang tebusan, diperoleh nilai $\mathrm{PPh}$ Badan berdasarkan tarif tax amnesty $0,5 \%$ dengan peredaran bruto kurang dari $\mathrm{Rp}$. 4.800.000.000,- pada CV. Yellow Duck periode 2016 adalah sebesar Rp. 11.417.040,--

Kata kunci : Peraturan Pemerintah 46 Tahun 2013, Penerpan PPh Badan, CV. Yellow Duck

* Sekolah Tinggi Ilmu Ekonomi Pancasetia Banjarmasin

Jl. A Yani Km. 5,5 Banjarmasin, Kalimantan Selatan

e-mail: yudi.rahman@gmail.com 


\section{Latar Belakang}

Pemasukan dana melalui pajak bagi pemerintah dengan sendirinya memegang porsi yang cukup penting bagi pendapatan negara. Berdasarkan hal tersebut maka pajak merupakan sumber dana utama yang digunakan untuk membiayai sebagian besar pembelanjaan negara. Berbagai upaya telah diupayakan pemerintah untuk menyempurnakan sistem perpajakan dan pemungutannya lebih diitensifkan. Salah satunya dengan perubahan UU perpajakan yang terus disesuaikan dengan situasi dan kondisi perekonomian dewasa ini, sehingga meskipun pemerintah menggenjot penerimaan pajak, salah satunya pajak penghasilan, namun tetap pengenaan pajak bagi wajib pajak tidak mengganggu iklim bisnis, iklim investasi maupun sektor riil.

Pajak penghasilan adalah pajak yang dikenakan kepada Subjek Pajak atas penghasilan yang diterima dalam satu tahun pajak. Subjek Pajak yang dimaksud adalah baik orang pribadi maupun badan (perusahaan). Penghasilan suatu perusahaan akan dihitung dari catatan, buku, serta dokumen pendukung lainnya yang dikelola dalam suatu sistem akuntansi yang dilakukan oleh perusahaan. Dari penghasilan perusahaan inilah yang akan dikenakan tarif pajak penghasilan. Pajak penghasilan merupakan bagian dari laba bersih perusahaan.

Bagi pemerintah, pajak mempunyai fungsi sebagai sumber penerimaan negara. Berdasarkan fungsi ini, pajak adalah bagian laba perusahaan yang seharusnya diberikan ke pemerintah untuk mendukung pembangunan nasional. Hal ini mengakibatkan semakin besar pajak yang disetorkan oleh perusahaan maka akan semakin baik bagi pemerintah. Di sisi yang lain, bagi perusahaan pajak lebih sering dianggap sebagai pos pengurang laba bersih yang seharusnya bisa diminimalkan oleh perusahaan. Pajak diakui sebagai elemen utama dalam kebijakan pengeluaran perusahaan. Bagi perusahaan, pajak penghasilan adalah bagian laba bersih yang dibagikan ke pihak lain (pemerintah), sehingga pajak akan mengurangi bagian laba.

Penerimaan negara yang bersumber dari pajak harus terus dikembangkan dan ditingkatkan sesuai dengan perkembangan perekonomian dan laju pembangunan nasional. Hal ini berdampak pada perubahan tarif pajak yang terjadi secara terus menerus dimulai dari Undang-Undang PPh No. 6 tahun 1983 sampai pada Undang-Undang PPh No. 36 tahun 2008. Undang-Undang PPh No. 36 tahun 2008 Pasal 17 Ayat (1) dan (2) menyatakan bahwa mulai tahun pajak 2009, tarif PPh Badan menganut sistem tarif tunggal yaitu 28\% dan akan menjadi $25 \%$ pada tahun 2010. Jadi berapapun penghasilan kena pajaknya, tarif yang dikenakan adalah satu yaitu $28 \%$ atau $25 \%$. Pajak yang harus disetor oleh Wajib Pajak Badan bergantung dari laba yang dihasilkan setiap tahunnya. Informasi yang terkandung dalam laba (earnings) memiliki peran penting dalam menilai kinerja perusahaan.

Untuk memudahkan penerimaan dan perhitungan dari sektor pajak di Indonesia sebagai penyumbang terbesar bagi pendapatan negara dan akan selalu ada selama di negara tersebut masih ada aktivitas ekonomi yang dilakukan oleh masyarakatnya. Aktivitas ekonomi masyarakat dari sektor usaha mikro, kecil, dan menengah, maka pada 1 Juli 2013 pemerintah menetapkan Peraturan Pemerintah Nomor 46 Tahun 2013 mengenai Pajak Penghasilan Final $1 \%$ bagi pelaku usaha yang memiliki peredaran bruto dibawah 4,8 miliar rupiah setahun (Peraturan Pemerintah Republik Indonesia Nomor 46 Tahun 2013).

Menurut pemerintah melalui Direktorat Jendral Pajak, Peraturan pemerintah ini dibuat karena pendapatan pajak dari sektor usaha kecil dan menengah belum maksimal. Diberlakukannya Peraturan Pemerintah (PP) Nomor 46 Tahun 2013 tentang PPh atas Penghasilan dari Usaha yang Diterima atau Diperoleh Wajib Pajak yang Memiliki Peredaran Bruto Tertentu, yang terbit tanggal 12 Juni 2013 dan mulai berlaku sejak 1 Juli 2013. Bagi Wajib Pajak Orang Pribadi dan Badan yang menerima penghasilan dari usaha dengan peredaran bruto (omzet) per tahun tidak melebihi Rp. 4.800.000.000,00 (empat miliar delapan 
ratus juta rupiah) dalam 1 (satu) Tahun Pajak, akan dikenai pajak dengan tarif Pajak Penghasilan (PPh) yang bersifat final sebesar 1\% (satu persen).

Sehingga dengan demikian, perhitungan pajak badan tidak lagi berdasarkan laba perusahaan, mengingat perusahaan akan memanfaatkan peluang untuk merekayasa angka laba (earning management) untuk meminimalkan beban pajak penghasilan yang harus dibayar oleh perusahaan. Namun, perhitungan berdasarkan omzet yang diterima perusahaan dengan tarif $1 \%$ dengan ketentuan nilai omzet tidak lebih dari Rp. 4.800.000.000,- per tahun.

Peraturan Pemerintah (PP) Nomor 46 Tahun 2013 ini bertujuan memberikan kemudahan kepada Wajib Pajak dalam melaksanakan pemenuhan kewajiban perpajakannya. Pernyataan ini memperjelas arah kebijakan yang memang ditujukan untuk memberikan kemudahan dan insentif bagi Wajib Pajak dalam memenuhi kewajiban perpajakannya. Dalam ketentuan perpajakan, seluruh Wajib Pajak, Badan maupun Orang Pribadi yang melakukan kegiatan usaha atau pekerjaan bebas diwajibkan untuk menyelenggarakan pembukuan, kecuali bagi Wajib Pajak Orang Pribadi yang melakukan kegiatan usaha atau pekerjaan bebas dengan peredaran bruto dalam satu tahun kurang dari $\mathrm{Rp} 4,8$ Miliar wajib menyelenggarakan pencatatan. Hal ini sesuai dengan prinsip self assessment yang saat ini digunakan dalam ketentuan perpajakan di Indonesia. Tanpa pembukuan atau pencatatan, mustahil Wajib Pajak dapat mengetahui laba usahanya, apalagi melaporkan pajaknya dengan benar. Oleh karena itu pemberlakuan PP Nomor 46 Tahun 2013 seharusnya dipandang sebagai fasilitas bagi Wajib Pajak karena memudahkan dalam penghitungan pajaknya. Dengan hanya melaporkan omset, kemudian membayarkan $1 \%$ dari omset tersebut sebagai $\mathrm{PPh}$, Wajib Pajak akan dipermudah dalam melaporkan pajaknya melalui Surat Pemberitahuan (SPT).

Perhitungan PPh badan dengan tarif tunggal berdasarkan Undang-Undang No. 36 Tahun 2008, dengan tarif $12,5 \%$ dari laba bersih pada laporan keuangan perusahaan dengan nilai pendapatan bruto tidak lebih dari Rp. 4.800.000.000,- menimbulkan kesulitan tersendiri bagi perusahaan dalam melakukan perhitungannya. Karena perhitungan $\mathrm{PPh}$ tersebut masih memperhitungan beban tetap dan beban temporer sebagai faktor pengurang dari nilai pendapatan kena pajak. Sehingga perhitungan pajak yang dilakukan oleh perusahaan terkadang berbeda dengan perhitungan pajak sesuai dengan peraturan perpajakan.

CV. Yellow Duck merupakan perusahaan percetakan dan event organizer yang berada di wilayah Banjarbaru. Berdasarkan fenomena saat ini, pihak perusahaan tidak pernah melakukan kewajibannya terutama dalam pembayaran pajak khususnya pajak penghasilan badan mulai berdirinya perusahaan di tahun 2013. Dengan nilai omzet kurang dari 5 milyard per tahun yaitu sebesar Rp. 2.283.408.000,- ditahun 2016, berdasarkan perhitungan PPh Badan dengan peraturan PP 46 Tahun 2013 dengan tarif 1\% dari pendapatan bruto dengan nilai tidak lebih dari Rp. 4.800.000.000,-, diharapkan nilai pajak badan tidak memberatkan bagi perusahaan untuk melaksanakan kewajibannya sebagai wajib pajak dalam melakukan pembayaran pajak badan usaha.

Sehubungan dengan tax amnesty yaitu penghapusan pajak yang seharusnya terutang, tidak dikenai sanksi administrasi perpajakan dan sanksi pidana di bidang perpajakan, dengan cara mengungkap harta dan membayar uang tebusan sebagaimana diatur dalam UndangUndang No 11 Tahun 2016 merupakan kebijakan pemerintah yang diberikan kepada pembayar pajak tentang forgiveness / pengampunan pajak, dan sebagai ganti atas pengampunan tersebut pembayar pajak diharuskan untuk membayar uang tebusan. Mendapatkan pengampunan pajak artinya data laporan yang ada selama ini dianggap telah diputihkan dan atas beberapa utang pajak juga dihapuskan.

Sementara untuk uang tebusan yang seharusnya dibayar untuk perusahaan dengan wajib pajak yang peredaran usahanya sampai dengan Rp. 4,8M (UMKM) dengan nilai harta $\leq$ Rp.10M maka tariff tebusannya adalah sebesar $0,5 \%$ dari nilai omzetnya. 


\section{Kajian Literatur}

Undang-Undang Republik Indonesia Nomer 28 Tahun 2007 menjelaskan bahwa pajak adalah kontribusi kepada negara yang terutang oleh orang pribadi atau badan yang bersifat memaksa berdasarkan Undang-undang, dengan tidak mendapatkan imbalan secara langsung dan digunakan untuk keperluan negara bagi sebesar-besarnya kemakmuran rakyat. Sementara menurut Mardiasmo (2013: 1) pajak adalah iuran rakyat kepada kas negara berdasarkan undang-undang dengan tiada mendapat jasa timbal (kontra-prestasi) yang langsung dapat ditujukan dan yang digunakan untuk membayar umum.

Resmi (2012: 35) menyatakan pajak dapat dikelompokkan menjadi tiga, yaitu pengelompokkan berdasarkan golongannya, lembaga pemungutnya, maupun sifatnya. Berdasarkan golongannya PPh juga mencakup Usaha Mikro, Kecil dan Menengah (UMKM) sebagai wajib pajaknya.

Penelitian mengenai perubahan Undang-Undang Perpajakan terutama UndangUndang Pajak Penghasilan, Jumlah Wajib Pajak dan kontribusinya terhadap penerimaan pajak telah dilakukan oleh peneliti-peneliti sebelumnya. Rindi Septi Coriah Nurwulan (2014) melakukan penelitian tentang bagaimana kontribusi pajak bumi dan bangunan terhadap pendapatan daerah. Dari penelitian tersebut menunjukkan besarnya kontribusi PBB terhadap pendapatan daerah tahun 2003-2007, rata-rata sebesar 4,05\% setiap tahun. Terlihat bahwa terjadi fluktuasi turun naik dalam penerimaan PBB.

Mengacu pada Waluyo (2013: 6), terdapat dua fungsi pajak yaitu:

1. Fungsi Penerimaan (Budgeter) yaitu sumber dana yang diperuntukkan bagi pembiayaan pengeluaran-pengeluaran pemerintah, misalnya dimasukkannya pajak dalam APBN sebagai penerimaan dalam negeri.

2. Fungsi Mengatur (Reguler) yaitu alat untuk mengatur atau melaksanakan kebijakan di bidang sosial dan ekonomi, misalnya dikenakannya pajak yang lebih tinggi terhadap minuman keras, dapat ditekan demikian pula terhadap barang mewah.

Undang-Undang Nomor 7 tahun 1983 tentang Pajak Penghasilan (PPh) yang telah diubah dengan Undang-Undang Nomor 7 tahun 1991. Undang-Undang Nomor 10 tahun 1994, Undang-Undang Nomor 17 Tahun 2000 dan terakhir diubah dengan UndangUndang Nomor 36 Tahun 2008 mengatur mengenai pajak atas penghasilan yang diterima atau diperoleh orang pribadi dan badan. Diana, Anastasia dan Lilis Setiawati (2015:163) menjelaskan bahwa pajak penghasilan dikenakan terhadap subjek pajak berkenaan dengan penghasilan yang diterima atau diperolehnya dalam tahun pajak. Subjek pajak yang menerima atau memperoleh penghasilan tersebut disebut sebagai Wajib Pajak (WP).

Menurut Judisseno, Rimsky K (2013: 47), pengertian pajak penghasilan adalah suatu pungutan resmi yang ditujukan kepada masyarakat yang berpenghasilan atau atas penghasilan yang diterima dan diperolehnya dalam tahun pajak untuk kepentingan negara dan masyarakat dalam hidup berbangsa dan bernegara sebagai suatu kewajiban yang harus dilaksanakannya. Sementara menurut Supramono dan Theresia (2012:20) pajak penghasilan adalah suatu pungutan resmi yang ditujukan kepada masyarakat yang berpenghasilan atau atas penghasilan yang diterima atau diperoleh dalam tahun pajak untuk membiayai pengeluaran-pengeluaran Negara.

Objek Pajak Penghasilan meliputi penghasilan yaitu setiap tambahan kemampuan ekonomis yang diterima atau diperoleh Wajib Pajak, baik yang berasal dari Indonesia maupun dari luar Indonesia, yang dapat dipakai untuk konsumsi atau menambah kekayaan Wajib Pajak yang bersangkutan, dengan nama dan dalam bentuk apapun (Diana, Anastasia dan Lilis Setiawati 2015: 173).

Secara garis besar, menurut Undang-undang Pajak Penghasilan, Objek pajak 
penghasilan meliputi:

1. Penggantian atau imbalan berkenaan dengan pekerjaan atau jasa yang diterima atau diperoleh termasuk gaji, upah, tunjangan, honorarium, komisi, bonus, gratifikasi, uang pensiun, atau imbalan dalam bentuk lainnya, kecuali ditentukan lain dalam Undang-undang ini;

2. Hadiah dari undian atau pekerjaan atau kegiatan dan perhargaan;

3. Laba usaha;

4. Keuntungan karena penjualan atau karena pengalihan harta termasuk:

a. Keuntungan karena pengalihan harta kepada perseroan, persekutuan, dan badan lainnya sebagai pengganti saham atau penyertaan modal;

b. Keuntungan karena pengalihan harta kepada pemegang saham, sekutu, atau anggota yang diperoleh perseroan, persekutuan, dan badan lainnya;

c. Keuntungan karena likuidasi, penggabungan, peleburan, pemekaran, pemecahan, pengambilalihan usaha, atau reorganisasi dengan nama dan dalam bentuk apapun;

d. Keuntungan karena pengalihan harta berupa hibah, bantuan, atau sumbangan, kecuali yang diberikan kepada keluarga sedarah dalam garis keturunan lurus satu derajat dan badan keagamaan, badan pendidikan, badan sosial termasuk yayasan, koperasi, atau orang pribadi yang menjalankan usaha mikro dan kecil, yang ketentuannya diatur lebih lanjut dengan Peraturan Menteri Keuangan, sepanjang tidak ada hubungan dengan usaha, pekerjaan, kepemilikan, atau penguasaan diantara pihak-pihak yang bersangkutan;

e. Keuntungan karena penjualan atau pengalihan sebagian atau seluruh hak penambangan, tanda turut serta dalam pembiayaan atau permodalan dalam perusahaan pertambangan

5. Penerimaan kembali pembayaran pajak yang telah dibebankan sebagai biaya dan pembayaran tambahan pengembalian pajak;

6. Bunga termasuk premium, diskonto dan imbalan karena jaminan pengembalian utang;

7. Dividen, dengan nama dan dalam bentuk apapun, termasuk dividen dari perusahaan asuransi kepada pemegang polis dan pembagian sisa hasil usaha koperasi;

8. Royalti atau imbalan atas penggunaan hak;

9. Sewa dan penghasilan lain sehubungan dengan penggunaan harta;

10. Penerimaan atau perolehan pembayaran berkala.

11. Keuntungan karena pembebasan utang, kecuali sampai dengan jumlah tertentu yang ditetapkan dengan Peraturan Pemerintah;

12. Keuntungan selisih kurs mata uang asing;

13. Selisih lebih karena penilaian kembali aktiva;

14. Premi asuransi;

15. Iuran yang diterima atau diperoleh perkumpulan dari anggotanya yang terdiri dari Wajib Pajak yang menjalankan usaha atau pekerjaan bebas;

16. Tambahan kekayaan neto yang berasal dari penghasilan yang belum dikenakan pajak;

17. Penghasilan dari usaha berbasis syariah;

18. Imbalan bunga sebagaimana dimaksud dalam Undang-Undang yang mengatur mengenai ketentuan umum dan tata cara perpajakan.

Salah satu bentuk reformasi perpajakan di Indonesia adalah dengan disahkannya Undang-Undang Nomor 36 Tahun 2008 yang merupakan perubahan keempat dari UndangUndang Nomor 7 Tahun 1983 tentang Pajak Penghasilan melalui proses panjang dan melibatkan stakeholder termasuk pengusaha yang mencerminkan keadilan dan kesetaraan kedudukan antara fiskus dan Wajib Pajak. Penurunan tarif, penekanan cost of compliance, 
law enforcement yang lebih tegas kepada Wajib Pajak tidak patuh, kesataraan fiskus dan Wajib Pajak merupakan poin-poin dalam tax reform UU PPh. Undang-Undang Nomor 36 Tahun 2008 ini disahkan pada tanggal 23 September 2008 dan mulai berlaku tanggal 1 Januari 2009. Pokok pikiran yang terdapat dalam Undang- Undang Nomor 36 Tahun 2008 tentang Perubahan Keempat Undang-Undang No.7 Tahun 1983 tentang Pajak Penghasilan antara lain sebagai berikut (Darmin Nasution, 2013):

1. Penurunan Tarif Pajak Penghasilan (PPh)

Penurunan tarif $\mathrm{PPh}$ dimaksudkan untuk menyesuaikan dengan tarif $\mathrm{PPh}$ negara-negara tetangga yang relatif lebih rendah sehingga dapat meningkatkan daya saing dalam negeri, mengurangi beban pajak, dan dapat meningkatkan kepatuhan Wajib Pajak (WP).

2. Pembebasan kewajiban pembayaran fiskal luar negeri bagi WP yang telah mempunyai NPWP fiskal sejak 2009 serta penghapusan pemungutan fiskal luar negeri pada tahun 2011.

Pembayaran fiskal luar negeri adalah pembayaran pajak di muka bagi orang pribadi yang akan bepergian ke luar negeri. Kebijakan penghapusan kewajiban pembayaran fiskal luar negeri bagi WP yang memiliki NPWP dimaksudkan untuk mendorong WP memiliki NPWP sehingga memperluas basis pajak. Diharapkan pada 2011 semua masyarakat yang wajib memiliki NPWP telah memiliki NPWP sehingga kewajiban pembayaran fiskal luar negeri layak dihapuskan.

3. Peningkatan nilai Penghasilan Tidak Kena Pajak (PTKP) untuk diri WP orang pribadi sebesar 20\% dari Rp 13,2 juta menjadi Rp 15,84 juta, sedangkan untuk tanggungan istri dan keluarga ditingkatkan sebesar $10 \%$ dari Rp 1,2 juta menjadi Rp 1,32 juta dengan paling banyak 3 tanggungan setiap keluarga. Hal ini dimaksudkan untuk menyesuaikan PTKP dengan perkembangan ekonomi dan moneter serta mengangkat pengaturannya dari peraturan Menteri Keuangan menjadi Undang-Undang.

4. Penerapan tarif pemotongan/ pemungutan $\mathrm{PPh}$ yang lebih tinggi bagi WP yang tidak memiliki NPWP

5. Perluasan biaya yang dapat dikurangkan dari penghasilan bruto. Dimaksudkan bahwa pemerintah memberikan fasilitas kepada masyarakat yang secara nyata ikut berpartisipasi dalam kepentingan sosial, dengan diperkenankannya biaya tersebut sebagai pengurang penghasilan bruto.

\section{Pengecualian dari objek PPh}

7. Sisa lebih yang diterima atau diperoleh lembaga atau badan nirlaba yang bergerak dalam bidang pendidikan dan atau bidang penelitian dan pengembangan yang ditanamkan kembali paling lama dalam jangka waktu 4 tahun tidak dikenai pajak.

Pajak Penghasilan (disingkat PPh) dikenakan terhadap Wajib Pajak dalam satu periode tertentu yang dinamakan tahun pajak. Berdasarkan hal ini, maka perhitungan dan penghitungan PPh dilakukan setahun sekali yang dituangkan dalam SPT Tahunan. Nah, karena penghitungan PPh dilakukan setahun sekali, maka penghitungan ini harus dilakukan setelah satu tahun tersebut berakhir agar semua data penghasilan dalam satu tahun sudah diketahui. Untuk perusahaan, tentu saja data penghasilan ini harus menunggu laporan keuangan selesai dibuat. 
Dengan cara seperti itu tentu saja jumlah PPh terutang yang wajib dibayar baru dapat diketahui ketika suatu tahun pajak telah berakhir. Agar pembayaran pajak tidak dilakukan sekaligus yang tentunya akan memberatkan, maka dibuatlah mekanisme pembayaran pajak di muka atau pembayaran cicilan setiap bulan. Pembayaran angsuran atau cicilan ini dinamakan Pajak Penghasilan Pasal 25.

Besarnya angsuran PPh Pasal 25 harus dihitung sesuai dengan ketentuan. Pada umumnya, cara menghitung PPh Pasal 25 didasarkan kepada data SPT Tahunan tahun sebelumnya. Artinya, kita mengasumsikan bahwa penghasilan tahun ini sama dengan penghasilan tahun sebelumnya. Tentu saja nanti akan ada perbedaan dengan kondisi sebenarnya ketika tahun pajak sekarang sudah berakhir. Selisih tersebutlah yang kita bayar sebagai kekurangan pajak akhir tahun. Kekurangan bayar akhir tahun ini biasa dinamakan $\mathrm{PPh}$ Pasal 29. Apabila selisihnya menunjukkan lebih bayar, maka kondisi ini dinamakan restitusi atau Wajib Pajak meminta kelebihan pembayaran pajak yang telah dilakukan.

Pada umumnya angsuran pajak ini adalah sebesar Pajak Penghasilan terutang menurut SPT Tahunan Pajak Penghasilan tahun lalu dikurangi dengan kredit pajak Pajak Penghasilan Pasal 21, 22, 23 dan Pasal 24, dibagi 12 atau banyaknya bulan dalam bagian tahun pajak.

Pajak Penghasilan Pasal 25 untuk bulan-bulan sebelum batas waktu penyampaian SPT Tahunan adalah sama besarnya dengan Pajak Penghasilan Pasal 25 bulan terakhir tahun pajak yang lalu. Apabila tahun pajaknya adalah tahun kalender (Januari-Desember), maka yang dimaksud dengan bulan-bulan sebelum batas waktu penyampaian SPT Tahunan adalah bulan Januari dan Februari. Dengan demikian PPh Pasal 25 bulan Januari dan Februari 2016 adalah sama dengan PPh Pasal 25 bulan Desember 2015.

PP No. 46 tahun 2013 membahas tentang pajak penghasilan atas penghasilan dari usaha yang diterima atau diperoleh wajib pajak yang memiliki peredaran bruto tertentu. Dimana ketentuan tersebut tercantum dalam pasal 2 ayat 2b PP 46 Tahun 2013, yaitu bagi wajib pajak orang pribadi dan badan yang penghasilan dari usaha dengan peredaran bruto (omzet) tidak melebihi Rp. 4.800.000.000,- (empat miliar delapan ratus juta rupiah) dalam 1 (satu) Tahun Pajak.

Pasal 3 ayat (1) dalam PP No.46 Tahun 2013 berbunyi "Besarnya tarif Pajak Penghasilan yang bersifat final sebagaimana dimaksud dalam Pasal 2 adalah 1\% (satu persen)" Pengenaan Pajak Penghasilan didasarkan pada peredaran bruto dari usaha dalam 1 (satu) tahun dari Tahun Pajak terakhir sebelum Tahun Pajak yang bersangkutan. Peraturan baru ini bersifat final dengan tarif $1 \%$ dari peredaran bruto. Sebelum peraturan baru ini, Wajib Pajak dengan peredaran bruto kurang dari Rp 4.800.000.000,00 dalam tahun pajak menggunakan Pajak Penghasilan Pasal 25 dengan tarif 12,5\% dari laba sebelum pajaknya.

Jika dalam hal peredaran bruto kumulatif Wajib Pajak pada suatu bulan telah melebihi jumlah Rp.4.800.000.000, (empat miliar delapan ratus juta rupiah) dalam suatu Tahun Pajak, Wajib Pajak tetap dikenai tarif Pajak Final sampai dengan akhir Tahun Pajak yang bersangkutan. Namun apabila dalam sudah masuk pada tahun pajak berikutnya maka dikenakan tarif pajak penghasilan berdasarkan ketentuan Undang -Undang Pajak Penghasilan.

Tarif PPh Final sesuai Peraturan Pemerintah No. 46 Tahun 2013 ditetapkan sebesar 1\% (satu persen), dan DPP untuk menghitung PPh Final adalah jumlah peredaran bruto setiap bulan dijelaskan dalam Pasal 3 ayat (1) dan Pasal 4 ayat (1) PP Nomor 46 Tahun 2013, yaitu:

1. Pasal 3 Peraturan Pemerintah No. 46 Tahun 2013

Ayat (1)

Besarnya tarif Pajak Penghasilan yang bersifat final sebagaimana dimaksud dalam Pasal 2 adalah $1 \%$ (satu persen). 
2. Pasal 4 Peraturan Pemerintah No. 46 Tahun 2013

Ayat (1)

Dasar pengenaan pajak yang digunakan untuk menghitung Pajak Penghasilan yang bersifat final sebagaimana dimaksud dalam pasal 2 ayat (1) adalah jumlah peredaran bruto setiap bulan.

Dengan demikian, PPh Final yang terutang yang harus dibayar setiap bulan oleh Wajib Pajak yang bersangkutan $=1 \%$ x peredaran bruto bulan tersebut.

Menurut Undang-undang Nomor 16 tahun 2009 tentang ketentuan umum dan tatacara perpajakan pasal 28 ayat (1) yaitu wajib pajak orang pribadi yang melakukan kegiatan usaha atau pekerjaan bebas dan wajib pajak badan di Indonesia wajib menyelenggarakan pembukuan. Hal ini jelas diatur dalam undang- undang bahwa wajib pajak badan harus melakukan pembukuan dalam kegiatan usahanya. Pembukuan sekurang-kurangnya terdiri atas catatan mengenai aset, kewajiban, ekuitas, penghasilan dan biaya serta penjualan dan pembelian sehingga dapat dihitung besarnya pajak terutang.

Menurut penjelasan Pasal 11 UU KUP No. 28 Tahun 2007 Restitusi adalah perhitungan jumlah pajak yang sebenarnya terutang dengan jumlah kredit pajak yang menunjukan jumlah selisih lebih (jumlah kredit pajak lebih besar daripada pajak yang terutang), atau telah dilakukan pembayaran pajak yang seharusnya tidak terutang. Wajib pajak berhak untuk meminta kembali kelebihan pembayaran pajak, dengan catatan wajib pajak tersebut tidak mempunyai utang pajak. Dasar hukum Restitusi, meliputi:

1. Undang-undang Nomor 6 Tahun 1983 tentang Ketentuan Umum Tata Cara Perpajakan sebagaimana telah diubah terakhir dengan Undang-undang Nomor 16 Tahun 2000;

2. Undang-undang Nomor 7 Tahun 1983 tentang Pajak Penghasilan sebagaimana telah diubah terakhir dengan Undang-undang Nomor 17 Tahun 2000;

3. Undang-undang Nomor 8 Tahun 1983 tentang Pajak Pertambahan Nilai Barang dan Pajak Penjualan atas Barang Mewah sebagaimana telah diubah terakhir dengan Undang-undang Nomor 18 Tahun 2002;

4. Keputusan Menteri Keuangan tentang Organisasi dan Tata Kerja Kantor Wilayah Direktorat Jenderal Pajak, Kantor Pelayanan Pajak Madya, dan Kantor Pelayanan Pajak Pratama di lingkungan Kantor Wilayah Direktorat Jenderal Pajak ;

5. Keputusan Menteri Keuangan Republik Indonesia Nomor 544/KMK.04/2000 tentang Kriteria Wajib Pajak Dapat Diberikan Pengembalian Pendahuluan Kelebihan Pembayaran Pajak;

6. Keputusan Menteri Keuangan Nomor 545/KMK.04/2000 Tanggal 22 Desember 2000 tentang Tata Cara Pemeriksaan;

7. Peraturan Direktur Jenderal Pajak KEP-142/PJ/2005 Tanggal 31 Agustus 2005 Petunjuk Pelaksanaan Pemeriksaan;

8. Keputusan Direktur Jenderal Pajak Nomor KEP-359/PJ/2003 Tanggal 4 November 2003 tentang Perubahan atas Keputusan Direktur Jenderal Pajak Nomor KEP-406/PJ/2001 tentang Tata Cara Penerbitan Surat Keputusan Pengembalian Pendahuluan Kelebihan Pajak;

9. Keputusan Direktur Jenderal Pajak Nomor KEP-550/PJ/2000 tentang Tata Cara Penetapan Wajib Pajak mematuhi Kriteria Tertentu dan Penyelesaian Permohonan Pengembaliann Kelebihan Pembayaran Pajak dalam rangka Pengembalian Pendahuluan Kelebihan Pembayaran Pajak.

Perlakuan akuntansi mengenai pajak penghasilan diatur oleh IAI melalui PSAK No. 46 tahun 2012 tentang penyajian pajak penghasilan pada laporan keuangan serta pengungkapan infomasi yang relevan. Penerapan Standar Akuntansi Keuangan (PSAK) Nomor 46 telah 
disahkan oleh pengurus Pusat IAI pada tanggal 23 Desember 1997 sampai sekarang masih berlaku PSAK No. 46.

Menurut Harnanto dalam buku Akuntansi Perpajakan (2012, h.110) standar akuntansi pajak penghasilan yang diatur dalam PSAK No.46 tentang akuntansi pajak penghasilan adalah suatu pajak penghasilan yang secara komprehensif mencoba menerapkan pendekatan aktiva kewajiban (asset- liability approach).

Pengertian Tax amnesty adalah penghapusan pajak yang seharusnya terutang, tidak dikenai sanksi administrasi perpajakan dan sanksi pidana di bidang perpajakan, dengan cara mengungkap Harta dan membayar Uang Tebusan sebagaimana diatur dalam Undang-Undang No 11 Tahun 2016 Tentang Pengampunan Pajak. Secara umum Pengertian Tax Amnesty adalah kebijakan pemerintah yang diberikan kepada pembayar pajak tentang forgiveness/ pengampunan pajak, dan sebagai ganti atas pengampunan tersebut pembayar pajak diharuskan untuk membayar uang tebusan. Mendapatkan pengampunan pajak artinya data laporan yang ada selama ini dianggap telah diputihkan dan atas beberapa utang pajak juga dihapuskan.

Menurut "UU No 11 Tahun 2016 Tentang Pengampunan Pajak" Tax Amnesty adalah penghapusan pajak yang seharusnya terutang, tidak dikenai sanksi administrasi perpajakan dan sanksi pidana di bidang perpajakan, dengan cara mengungkap Harta dan membayar Uang Tebusan sebagaimana diatur dalam Undang-Undang ini.

Menurut "PMK No. 118/PMK.03/2016" Tax Amnesty adalah adalah penghapusan pajak yang seharusnya terutang, tidak dikenai sanksi administrasi perpajakan dan sanksi pidana di bidang perpajakan, dengan cara mengungkap Harta dan membayar Uang Tebusan sebagaimana diatur dalam Undang-Undang Pengampunan Pajak.

Latar belakang Tax Amnesty atau mengapa Indonesia perlu memberikan tax amnesty kepada para pembayar pajak (wajib pajak) diantaranya adalah sebagai berikut :

1. Penyebab Pertama Indonesia memberlakukan Tax Amnesty adalah karena terdapat Harta milik warga negara baik di dalam maupun di luar negeri yang belum atau belum seluruhnya dilaporkan dalam Surat Pemberitahuan Tahunan Pajak Penghasilan;

2. Tax Amnesty adalah untuk meningkatkan penerimaan negara dan pertumbuhan perekonomian serta kesadaran dan kepatuhan masyarakat dalam pelaksanaan kewajiban perpajakan, perlu menerbitkan kebijakan Pengampunan Pajak;

3. Kasus Panama Pappers

Dari ketiga latar belakang tax amnesty tersebut maka presiden republik Indonesia pada tanggal 1 Juli 2016 mengesahkan Undang Undang Tax Amnesty Nomor 11 Tahun 2016 Tentang Pengampunan Pajak. Subjek Tax Amnesty adalah warga negara Indonesia baik yang ber NPWP maupun tidak yang memiliki harta lain selain yang telah dilaporkan dalam SPT Tahunan Pajak (warga negara yang pembayaran pajaknya selama ini masih belum sesuai dengan kondisi nyata). Objek Tax Amnesty adalah Harta yang dimiliki oleh Subjek Tax Amnesty, artinya yang menjadi sasaran dari pembayaran uang tebusan adalah atas Harta baik itu yang berada di dalam negeri maupun diluar negeri.

\section{Metode Penelitian}

Jenis penelitian yang digunakan adalah penelitian deskriptif yaitu penelitian yang digunakan untuk menggambarkan, menjelaskan dan menjawab persoalan-persoalan tentang fenomena dan peristiwa yang terjadi saat ini. Pola-pola penelitian deskriptif ini antara lain: survey, studi kasus, korelasional, dan pengembangan, dengan tujuan untuk menjelaskan suatu fenomena, mengumpulkan informasi yang bersifat aktual dan fuktual berdasarkan fenomena yang ada, mengidentifikasi masalah-masalah atau melakukan justifikasi kondisi-kondisi dan praktik-praktik yang sedang berlangsung dan memperoleh keuntungan dari pengalaman 
mereka untuk membuat rencana dan keputusan di masa yang akan datang. Tujuan dari penelitian deskriptif adalah menghasilkan gambaran akurat tentang sebuah kelompok, menggambarkan mekanisme sebuah proses atau hubungan, memberikan gambaran lengkap baik dalam bentuk verbal atau numerical.

Dalam melakukan penelitian ini jenis data yang digunakan ialah data kualitatif dan kuantitatif.

1. Data kualitatif yaitu variasi data yang diberikan oleh sumber yang sifatnya sangat beragam. Data kualitatif berupa: nama dan bentuk perusahaan, sejarah perusahaan, lokasi perusahaan dan bidang usaha.

2. Data Kuantitatif adalah data yang didapat diobyek penelitian dalam bentuk angka, misal data ini adalah data jumlah karyawan dan data operasional perusahaan

Sumber data yang digunakan dalam penelitian ini adalah data primer dan data sekunder, yaitu:

1. Data Primer

Yaitu data yang diperoleh langsung dari sumbernya dengan cara hasil wawancara atau interview dengan pengelola perusahaan atau dengan pihak yang memiliki kewenangan untuk memberikan keterangan atas permasalahan yang diajukan pada saat penelitian.

\section{Data Sekunder}

Yaitu data yang secara tidak langsung diperoleh dari CV. Yellow Duck yang berupa catatan atau literatur yang diperlukan untuk penelitian ini. Data sekunder ini diantaranya adalah profil CV. Yellow Duck sebagai obyek penelitian, struktur organisasi, jumlah anggota dan laporan keuangan.

Teknik pengumpulan data yang dilakukan penulis dalam penelitian ini menggunakan beberapa diantaranya:

1. Studi Lapangan (Field Research)

Yaitu pengumpulan data langsung dari sumber penelitian, adapun cara yang dilakukan adalah sebagai berikut :

a. Observasi yaitu dengan cara mengamati aktivitas kegiatan yang dilakukan oleh CV. Yellow Duck guna pengambilan data yang sesuai dengan apa yang diperlukan.

b. Wawancara, yaitu pengumpulan data dengan melakukan tanya jawab langsung secara mendalam dengan pihak CV. Yellow Duck, yang berhubungan dengan topik yang diteliti.

c. Dokumentasi, yaitu mengumpulkan data dan informasi melalui buku-buku, jurnal, internet dan melakukan penelitian terhadap dokumen-dokumen dan laporan keuangan CV. Yellow Duck yang berkaitan dengan penelitian.

2. Studi Pustaka (Library Research)

Yaitu mengumpulkan materi-materi yang digunakan sebagai landasan teori yang berkaitan dengan masalah yang diteliti terutama mengenai pajak PPh Badan berdasarkan PP 46 tahun 2013 pada CV. Yellow Duck.

Penelitian ini menggunakan metode analisis deskriptif yaitu peneliti mendeskripsikan hasil temuannya yang berasal dari data-data dari subyek penelitian, yang diinterpretasikan dalam bentuk narasi argumentatif yang memberikan gambaran secara umum, sehingga memberikan kesimpulan akhir dari penelitian tersebut. 


\section{Hasil Penelitian dan Pembahasan}

Hasil analisis terhadap Penerapan PPh badan final berdasarkan Peraturan Pemerintah No. 46 Tahun 2013 pada CV. Yellow Duck Banjarbaru akan dijabarkan kedalam poin-poin berikut:

1. Perhitungan Pajak PPh Badan Berdasarkan PP 46 Tahun 2013

Sesuai dengan tarif baru PPh Badan berdasarkan Peraturan pemerintah Nomor 46 tahun 2013 yaitu sebesar 1\% dari omzet pertahun kurang dari Rp. 4.800.000.000,-, maka perlakuan pajak $\mathrm{PPh}$ Badan yang seharusnya diterapkan oleh $\mathrm{CV}$. Yellow Duck berdasarkan peraturan tersebut, mengingat selama ini perusahaan tidak melakukan kewajiban dalam membayar pajak badan.

Berikut perhitungan PPh Badan berdasarkan PP 46 tahun 2013 dengan pemotongan yang dilakukan per bulan berdasarkan PPh Pasal 4 ayat 2 pada CV. Yellow Duck:

Tabel 1. Perhitungan PPh Badan Per bulan (PPh Per Pasal 4 ayat (2) ) Berdasarkan PP 46 Tahun 2013 CV. Yellow Duck

\begin{tabular}{llrrrr}
\hline \multicolumn{1}{c}{ Bulan } & \multicolumn{2}{c}{ Peredaran Bruto } & Tarif Pajak & \multicolumn{2}{c}{ PPh Pasal 4 ayat 2 } \\
\hline Januari & $\mathrm{Rp}$ & $193,460,000$ & $1 \%$ & $\mathrm{Rp}$ & $1,934,600$ \\
\hline Februari & $\mathrm{Rp}$ & $205,978,000$ & $1 \%$ & $\mathrm{Rp}$ & $2,059,780$ \\
\hline Maret & $\mathrm{Rp}$ & $189,300,000$ & $1 \%$ & $\mathrm{Rp}$ & $1,893,000$ \\
\hline April & $\mathrm{Rp}$ & $203,780,000$ & $1 \%$ & $\mathrm{Rp}$ & $2,037,800$ \\
\hline Mei & $\mathrm{Rp}$ & $178,430,000$ & $1 \%$ & $\mathrm{Rp}$ & $1,784,300$ \\
\hline Juni & $\mathrm{Rp}$ & $189,100,000$ & $1 \%$ & $\mathrm{Rp}$ & $1,891,000$ \\
\hline Juli & $\mathrm{Rp}$ & $201,284,000$ & $1 \%$ & $\mathrm{Rp}$ & $2,012,840$ \\
\hline Agustus & $\mathrm{Rp}$ & $190,303,000$ & $1 \%$ & $\mathrm{Rp}$ & $1,903,030$ \\
\hline September & $\mathrm{Rp}$ & $175,301,000$ & $1 \%$ & $\mathrm{Rp}$ & $1,753,010$ \\
\hline Oktober & $\mathrm{Rp}$ & $159,102,000$ & $1 \%$ & $\mathrm{Rp}$ & $1,591,020$ \\
\hline November & $\mathrm{Rp}$ & $198,340,000$ & $1 \%$ & $\mathrm{Rp}$ & $1,983,400$ \\
\hline Desember & $\mathrm{Rp}$ & $199,030,000$ & $1 \%$ & $\mathrm{Rp}$ & $1,990,300$ \\
\hline Jumlah & $\mathrm{Rp}$ & $2,283,408,000$ & & $\mathrm{Rp}$ & $22,834,080$ \\
\hline
\end{tabular}

Berdasarkan data diatas, nilai PPh Badan CV. Yellow Duck tersebut merupakan nilai yang seharusnya disetorkan setiap bulan paling lambat tanggal 15 bulan berikutnya dengan Kode Jenis Setoran Pajak 411128-420.

Namun mengingat belum pernah dilakukan pembayaran PPh Badan sebelumnya, maka nilai perhitungan PPh Badan CV. Yellow Duck berdasarkan PP 46 Tahun 2013 dengan peredaran bruto dalam satu tahun kurang dari Rp. 4.800.000.000,- yaitu sebesar Rp. 2.283.408.000,-

Tabel 2. Perhitungan Pajak Berdasarkan Tarif 1\% dari Omzet sesuai PP No. 46 tahun 2013

\begin{tabular}{lc}
\hline \multicolumn{1}{c}{ URAIAN } & 2016 \\
\hline PENDAPATAN & \\
\hline Pendapatan & $2,283,408,000$ \\
\hline Pendapatan lain-lain & - \\
\hline Total Pendapatan Bruto & $2,283,408,000$ \\
\hline Tarif Pajak 1\% & $22,834,080$ \\
\hline
\end{tabular}

Nilai total PPh Badan CV. Yellow Duck berdasarkan peredaran bruto Rp. 2.283.408.000,maka diperoleh nilai total PPh Badan dalam satu tahun adalah Rp. 22.834.080,-. Berikut jurnal pengakuan pajak berdasarkan PP 46 Tahun 2013: 
Tabel 3. Jurnal Pajak Penghasilan

\begin{tabular}{llll}
\hline Tanggal & Keterangan & Debit & Kredit \\
\hline 31 Des 2016 & $\begin{array}{c}\text { PPh Badan } \\
\text { Kas }\end{array}$ & $22.834 .080,-$ & \\
& & & $22.834 .080,-$ \\
\hline
\end{tabular}

Sementara untuk wajib pajak selama 4 tahun kebelakang karena selama ini tidak ada pelaporan SPT, maka menurut forum pertanyaan mengenai amnesty pajak yang di publikasikan melalui http://www.ortax.org, pada pertanyaan no 33, dinyatakan bahwa: "WP sudah punya NPWP sebelum 2015 dan belum pernah menyampaikan SPT sekalipun. Sehingga perlakuan WP untuk harta yang diungkapkan oleh WP tersebut dalam SPT PPh Terakhir adalah hanya Harta yang bersumber dari penghasilan pada Tahun Pajak Terakhir. Jadi dengan demikian, untuk kewajiban bayar pajak untuk tahun 2016 ke belakang dianggap hangus, karena belum pernah melaporkan SPT pajak.

2. Perhitungan PPh Badan berdasarkan Tax Amnesti Pajak

Pengertian Tax amnesty adalah penghapusan pajak yang seharusnya terutang, tidak dikenai sanksi administrasi perpajakan dan sanksi pidana di bidang perpajakan, dengan cara mengungkap Harta dan membayar Uang Tebusan sebagaimana diatur dalam UndangUndang No 11 Tahun 2016 Tentang Pengampunan Pajak.

Secara umum Pengertian Tax Amnesty adalah kebijakan pemerintah yang diberikan kepada pembayar pajak tentang forgiveness/ pengampunan pajak, dan sebagai ganti atas pengampunan tersebut pembayar pajak diharuskan untuk membayar uang tebusan. Mendapatkan pengampunan pajak artinya data laporan yang ada selama ini dianggap telah diputihkan dan atas beberapa utang pajak juga dihapuskan.

Uang tebusan dihitung dengan mengalikan tarif dengan Dasar Pengenaan Uang Tebusan yaitu nilai Harta bersih yang belum atau belum seluruhnya dilaporkan dalam SPT Tahunan $\mathrm{PPh}$ Terakhir. Berdaskan tarif tax amnesty tersebut, maka perhitungan nilai $\mathrm{PPh}$ Badan Yellow Duck adalah sebagai berikut:

Tabel 4. Perhitungan PPh Badan CV. Yellow Duck Pajak Berdasarkan Tax Amnesty

\begin{tabular}{lc}
\hline \multicolumn{1}{c}{ URAIAN } & 2016 \\
\hline PENDAPATAN & $2,283,408,000$ \\
\hline Pendapatan & $2,283,408,000$ \\
\hline Pendapatan lain-lain & $11,417,040$ \\
\hline Total Pendapatan Bruto & \\
\hline Tarif Pajak 0,5\% & \\
\hline
\end{tabular}

Dari perhitungan $\mathrm{PPh}$ Badan berdasarkan tariff tax amnesty dengan peredaran bruto kurang dari Rp. 4.800.000.000,- pada CV. Yellow Duck periode 2016 adalah sebesar Rp. 11.417.040,-.

Tabel 5. Jurnal Pajak Penghasilan

\begin{tabular}{llll}
\hline Tanggal & Keterangan & Debit & Kredit \\
\hline 31 Des 2016 & PPh Badan & $11.417 .040,-$ & \\
& Kas & & 11.417 .040 \\
\hline
\end{tabular}


Tabel 6. Penyajian Laporan Keuangan Laporan Laba Rugi CV. Yellow Duck Periode 31 Desember 2016

\begin{tabular}{|c|c|c|c|}
\hline & \multicolumn{2}{|c|}{ PP 46 Tahun 2013} & $\begin{array}{c}\text { PP } 46 \text { Th } 2013+\text { Tax } \\
\text { Amnesty }\end{array}$ \\
\hline \multicolumn{4}{|l|}{ PENDAPATAN } \\
\hline Penjualan & & $\underline{2,283,408,000}$ & $\underline{2,283,408,000}$ \\
\hline Total Pendapatan & & $2,283,408,000$ & $2,283,408,000$ \\
\hline \multicolumn{4}{|l|}{$\begin{array}{l}\text { HARGA POKOK } \\
\text { PENJUALAN }\end{array}$} \\
\hline $\begin{array}{l}\text { Persediaan Awal Bahan } \\
\text { Baku }\end{array}$ & $107,573,000$ & \multicolumn{2}{|r|}{$107,573,000$} \\
\hline Harga Pokok Produksi & $512,010,000$ & \multicolumn{2}{|r|}{$512,010,000$} \\
\hline Persediaan Akhir & $(129,356,000)$ & \multicolumn{2}{|r|}{$(129,356,000)$} \\
\hline HPP & & $490,227,000$ & $490,227,000$ \\
\hline Laba Kotor & & $1,793,181,000$ & $1,793,181,000$ \\
\hline \multicolumn{4}{|l|}{ BIAYA-BIAYA } \\
\hline Beban Administrasi & $5,910,000$ & & $5,910,000$ \\
\hline Biaya transportasi & $45,084,000$ & & $45,084,000$ \\
\hline Biaya listrik, telpon & $155,493,840$ & & $155,493,840$ \\
\hline Biaya gaji karyawan & $525,980,000$ & & $525,980,000$ \\
\hline $\begin{array}{l}\text { Biaya Penyusutan } \\
\text { gedung }\end{array}$ & $23,160,000$ & & $23,160,000$ \\
\hline $\begin{array}{l}\text { Biaya Penyusutan } \\
\text { kendaraan }\end{array}$ & $18,580,000$ & & $18,580,000$ \\
\hline $\begin{array}{l}\text { Biaya penyusutan } \\
\text { peralatan }\end{array}$ & & \\
\hline $\begin{array}{l}\text { Biaya Perawatan } \\
\text { kendaraan }\end{array}$ & $9,072,000$ & \multicolumn{2}{|r|}{$9,072,000$} \\
\hline $\begin{array}{l}\text { Biaya Perawatan } \\
\text { peralatan }\end{array}$ & $3,900,000$ & \multicolumn{2}{|r|}{$3,900,000$} \\
\hline Biaya Promosi & $15,274,000$ & \multicolumn{2}{|r|}{$15,274,000$} \\
\hline Beban lain-lain & $\underline{4,418,750}$ & \multicolumn{2}{|r|}{$, 418,750$} \\
\hline & & $\underline{806,872,590}$ & $\underline{806,872,590}$ \\
\hline $\begin{array}{l}\text { Laba / Rugi Sebelum } \\
\text { Pajak }\end{array}$ & \multicolumn{2}{|r|}{$986,308,410$} & $986,308,410$ \\
\hline Pajak PPh & \multirow{2}{*}{\multicolumn{2}{|c|}{$\frac{22,834,080}{963,474,330}$}} & $\underline{11,417,040}$ \\
\hline $\begin{array}{l}\text { Laba / Rugi Sesudah } \\
\text { Pajak }\end{array}$ & & & $974,891,370$ \\
\hline
\end{tabular}

Berdasarkan laporan laba rugi pada Tabel 6, untuk nilai laba setalah dikurangi pajak PPh Badan berdasarkan PP 46 Tahun 2013 sebesar Rp. 963.474.330, sementara laporan laba rugi dengan nilai $\mathrm{PPh}$ Badan berdasarkan Tax Amnesty diperoleh laba sebesar Rp. 974.891.370,- 
Tabel 7. Laporan Neraca CV. Yellow Duck Periode 31 Desember 2016

\begin{tabular}{lrr}
\hline \multicolumn{1}{c}{ PERKIRAAN } & PP 46 Tahun 2013 & $\begin{array}{r}\text { PP 46 Th 2013 + Tax } \\
\text { Amnesty }\end{array}$ \\
\hline ASET & & \\
\hline Aset Lancar & $178,145,172$ & $178,145,172$ \\
\hline Kas dan Setara Kas & $75,026,000$ & $15,026,000$ \\
\hline Piutang & $129,356,000$ & $\mathbf{3 8 2 , 5 2 7 , \mathbf { 1 7 2 }}$ \\
\hline Persediaan & $\mathbf{3 8 2 , 5 2 7 , \mathbf { 1 7 2 }}$ & \\
\hline Jumlah Aset Lancar & & $1,328,390,000$ \\
\hline & & $(212,052,000)$ \\
\hline Aset Tetap & $1,328,390,000$ & \\
\hline Aset Tetap & $(212,052,000)$ & $\mathbf{1 , 1 1 6 , 3 3 8 , 0 0 0}$ \\
\hline Akumulasi Penyusutan Aset Tetap & $\mathbf{1 1 6 , 3 3 8 , 0 0 0}$ & \\
\hline Jumlah Aset Tetap & & \\
\hline
\end{tabular}

\section{TOTAL ASET}

$1,498,865,172$

$1,498,865,172$

\section{KEWAJIBAN DAN EKUITAS}

Kewajiban Lancar

\begin{tabular}{lrr}
\hline Hutang Dagang & $37,523,040$ & $37,523,040$ \\
\hline Hutang Bank & $64,721,450$ & $64,721,450$ \\
\hline Uang Muka Penjualan & $12,950,000$ & $12,950,000$ \\
\hline Hutang Pajak & $22,834,080$ & $11,417,040$ \\
\hline Jumlah Hutang Lancar & $\mathbf{1 3 8 , 0 2 8 , 5 7 0}$ & $\mathbf{1 2 6 , 6 1 1 , 5 3 0}$ \\
\hline
\end{tabular}

\begin{tabular}{lrr}
\hline Ekuitas & & \\
\hline Modal & $688,980,272$ & $688,980,272$ \\
\hline Laba di Tahan & $946,856,330$ & $958,273,370$ \\
\hline Pengurangan/ Penambahan Modal & $\underline{(275,000,000)}$ & $\underline{(275,000,000)}$ \\
\hline Jumlah Ekuitas & $\mathbf{1 , 3 6 0 , 8 3 6 , 6 0 2}$ & $\mathbf{1 , 3 7 2 , 2 5 3 , 6 4 2}$ \\
\hline & & \\
\hline TOTAL KEWAJIBAN DAN & $\mathbf{1 , 4 9 8 , 8 6 5 , 1 7 2}$ & $\mathbf{1 , 4 9 8 , 8 6 5 , 1 7 2}$ \\
EKUITAS & & \\
\hline
\end{tabular}

Berdasarkan laporan neraca diatas, dimana untuk nilai ekuitas dengan diterapkan $\mathrm{PPh}$ Badan berdasarkan PP 46 Tahun 2013 diperoleh nilai sebesar Rp. 1.360.836.602,- dengan total kewajiban lancar karena bertambah hutang pajak menjadi Rp. 138.028.570,-. Sementara laporan neraca berdasarkan tax amnensty nilai ekuitas bertambah menjadi Rp. 1.372.253.642,- dengan total kewajiban lancar sebesar Rp. 126.611.530,--

Pajak merupakan hal terpenting dari sebuah kewajiban yang harus dibayar oleh sebuah perusahaan. pengenaan tarif pajak ditujukan untuk meringankan bagi pihak wajib pajak. Berdasarkan perhitungan PPh badan sesuai PP 46 tahun 2013, pada CV. Yellow Duck ke depannya bisa lebih taat dalam melakukan pembayaran pajak dengan melakukan perhitungan 
yang lebih sederhana.

Tax Amnesty merupakan kebijakan pemerintah yang diberikan kepada pembayar pajak tentang forgiveness/ pengampunan pajak, dan sebagai ganti atas pengampunan tersebut pembayar pajak diharuskan untuk membayar uang tebusan, peraturan ini untuk meringankan bagi wajib pajak, namun berlaku pada suatu waktu berdasarkan peraturan pemerintah.

\section{Kesimpulan}

Berdasarkan penelitian skripsi oleh penulis dengan judul: Penerapan PPh Badan Final berdasarkan Peraturan Pemerintah Nomor 46 Tahun 2013 pada CV. Yellow Duck Banjarbaru, memberikan kesimpulan bahwa: Perhitungan tarif baru berdasarkan PP No. 46 tahun 2013 tidak perlu dilakukan koreksi fiskal, karena perhitungannya bukan dari laba bersih, melainkan dari peredaran bruto. Sehingga diharapkan kedepannya, dari hasil penelitian memberikan masukan pada pihak CV. Yellow Duck, untuk diterapkan dan dilakukan pembayaran pada tahun-tahun kedepannya. Penerapan PPh badan final berdasarkan Peraturan Pemerintah No. 46 Tahun 2013 pada CV. Yellow Duck Banjarbaru dengan nilai peredaran bruto per tahun kurang dari Rp. 4.800.000.000,- yaitu sebesar Rp. 2.283.408.000,- pada periode tahun 2016 dengan tarif PPh Badan 1\% maka diperoleh nilai total PPh Badan Rp. 22.834.080,-.

Sementara dengan adanya tax amnesty yaitu kebijakan pemerintah yang diberikan kepada pembayar pajak tentang forgiveness/ pengampunan pajak, dan sebagai ganti atas pengampunan tersebut pembayar pajak diharuskan untuk membayar uang tebusan, diperoleh nilai $\mathrm{PPh}$ Badan berdasarkan tarif tax amnesty $0,5 \%$ dengan peredaran bruto kurang dari Rp. 4.800.000.000,- pada CV. Yellow Duck periode 2016 adalah sebesar Rp. 11.417.040,-.

Berdasarkan pada serangkaian kesimpulan diatas, maka dalam penelitian ini penulis memberikan saran:

1. Dengan diberlakunya tarif baru PPh badan berdasarkan Peraturan Pemerintah Nomor 46 tahun 2013 dengan perhitungan yang lebih sederhana yaitu perhitungan bukan dari laba bersih, melainkan dari peredaran bruto, diharapkan kepada perusahaan CV. Yellow Duck, untuk diterapkan dan dilakukan pembayaran pada tahun-tahun kedepannya.

2. Dari hasil penelitian ini semoga bisa menjadikan rujukan pada penelitian kedepannya tentang perpajakan khususnya pajak penghasilan badan dengan dasar PP No. 46 Tahun 2013.

3. Hasil penelitian ini bisa menjadi bahan pertimbangan bagi masyarakat yang melakukan perhitungan PPh Badan pada perusahaannya dengan menggunakan tarif berdasarkan PP No. 46 tahun 2013.

\section{DAFTAR PUSTAKA}

Anonim. Peraturan Pemerintah Republik Indonesia Nomor 46 Tahun 2013 tentang Pajak Penghasilan atas Penghasilan dari Usaha yang Diterima atau Diperoleh Wajib Pajak yang Memiliki Peredaran Bruto tertentu.

Anonim. Undang-Undang Nomor 36 Tahun 2008 tentang Perubahan Keempat atas UndangUndang Nomor 7 Tahun 1983 tentang Pajak Penghasilan.

Butar-Butar, Etha Yuny Agustina, 2014, Penerapan PP No. 46 Tahun 2013 Pada CV. Lestari Malang. Fakultas Ekonomi, Jurusan Akuntansi Universitas Brawijaya, Malang, https://scholar.google.co.id/

scholar?hl=id\&as_sdt=0\%2C $5 \& q=2 . \% 09$ Etha + Yuny+Agustina + Butar+Butar $\% 2 \mathrm{C}+201$

$4 \% 2 \mathrm{C}+\% \mathrm{E} 2 \% 80 \% 9 \mathrm{CPenerapan}+\mathrm{PP}+$ No.+46+Tahun+2013+Pada+CV.+Lestari+Malan g\&btnG=, (Diakses Tanggall Oktober 2017)

Darmin Nasution. 2013. Kepatuhan Pajak. Kompas Gramedia

Dewi, Anak Agung Ayu Puspita, 2015, Penerapan PP No. 46 Tahun 2013 Pada CV. Sukarta Karya Sejahtera, Fakultas ekonomi, Universitas Udayana. 
Diana, Anastasia, Lilis Setiawati, 2015, Perpajakan Indonesia konsep, aplikasi,penuntun praktis, CV. ANDI OFFSET, Yogyakarta.

Dianaswara, Sindari, 2013, Analisis Perbandingan Penerapan PP no 46 tahun 2013 dengan UU no 36 tahun 2008 pada PT Trio Infotek Batam, Program Studi Akuntansi Politeknik Negeri Batam

Harnanto. 2012. Akuntansi Perpajakan. BPFE, Yogyakarta

Ikatan Akuntansi Indonesia, 2012. Pernyataan Standar Akuntansi Indonesia, Salemba Empat, Jakarta

Judisseno, Rimsky K, 2013, Perpajakan. Jakarta: PT. Gramedia Pustaka Utama.

Keliat, Margaretha. 2014. Analisis atas Pajak Tangguhan Studi Kasus Pada PT Wika Realty. Thesis. Fakultas Ekonomi - Universitas Indonesia. Jakarta.

Mardiasmo, 2013, Perpajakan. Edisi Revisi 2012 .Yogyakarta: Penerbit Andi.

Resmi, Siti 2012, Perpajakan Teori dan Kasus, Edisi Enam Buku Satu, Salemba Empat, Jakarta.

Supramono dan Theresia Woro Damayanti. 2012. Perpajakan Indonesia. Yogyakarta: Andi Offset

Waluyo, 2013, Perpajakan Indonesia. Salemba Empat, Jakarta 